\title{
An Overview of the Existing Schemes and Research Trends in Financing the Energy Upgrade of Buildings in Europe
}

\section{Christiana Panteli}

Frederick University, Cyprus, School of Engineering, 7, Y. Frederickou Str. Pallouriotisa, Nicosia 1036 Cyprus Cleopa GmbH, Neuendorfstr. 18b LT-16761 Hennigsdorf, Germany

\section{Eglè Klumbytè, Rasa Apanavičienè}

Kaunas University of Technology, Faculty of Civil Engineering and Architecture, Studentu st. 48, LT-51367 Kaunas, Lithuania

\section{Paris A. Fokaides*}

Frederick University, Cyprus, School of Engineering, 7, Y. Frederickou Str. Pallouriotisa, Nicosia 1036 Cyprus

Kaunas University of Technology, Faculty of Civil Engineering and Architecture, Studentu st. 48, LT-51367 Kaunas, Lithuania

*Corresponding author: eng.fp@frederick.ac.cy

\section{Crossef http://dx.doi.org/10.5755/j01.sace.27.2.25465}

Financial supporting schemes for the energy upgrading of the building sector in Europe constitute one of the major policies of the European Union (EU). Since the beginning of the 2000s, dozens of funding programs and initiatives have been announced by the European Commission (EC). It is a fact that the majority of these policies have borne fruit, as the metrics on both energy savings in the building sector and the promotion of renewable energy in the built environment have turned the EU into a global pioneer. This paper attempts to give a brief overview of the main policy and financial tools for the energy upgrading of the built environment in Europe. Emphasis is placed on three major mechanisms, which concern different-scale projects: crowdfunding projects, public-private co-financing projects, and large-scale projects funded by financial institutions such as European Investment Bank (EIB). Some of the significant findings of this study revealed that the energy-related funding schemes penetration defers in European member states in terms of advancement and implementation status. Reference is also made to recently implemented EU funded research programs in this field. This work aspires to constitute a reference study for future research activities in the field of financial supporting schemes for energy upgrading of buildings in Europe.

Keywords: Funding schemes, crowdfunding, public-private-partnership, energy upgrade, buildings, energy efficiency.

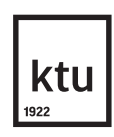

Journal of Sustainable Architecture and Civil Engineering Vol. 2 / No. 27 / 2020 pp. $53-62$ DOI 10.5755/j01.sace.27.2.25465 


\section{List of Abbreviations}

\begin{tabular}{l|l}
\hline EC & European Commission \\
\hline EPBD & Energy Performance of Buildings Directive \\
\hline PPP & Public-private partnership \\
\hline EIB & European Investment Bank \\
\hline EPCs & Energy Performance Certificates \\
\hline SFSB & Smart Finance for Smart Buildings \\
\hline PDA & Project Development Assistance \\
\hline ETS & Emission trading scheme \\
\hline
\end{tabular}

\begin{tabular}{l|l}
\hline PPAs & Power purchase agreements \\
\hline ESCO & Energy service companies \\
\hline EPC & Energy Performance Contracting \\
\hline EERSF & Energy Efficiency and Renewable Sources Fund \\
\hline EEEF & European Energy Efficiency Fund \\
\hline ERDF & The European Regional Development Fund \\
\hline JESSICA & $\begin{array}{l}\text { The Joint European Support for Sustainable } \\
\text { Investment in City Areas }\end{array}$ \\
\hline ELENA & The European Local Energy Assistance
\end{tabular}

The 2012 Energy Efficiency Directive established and mandate a set of measures dedicated to the achievement of the 20\% energy efficiency target by 2020 (EC 2012). According to the Directive, the European Union (EU) countries are required to improve energy efficiency in all stages of the energy chain. On 30th November 2016, the European Commission (EC) amended the Energy Efficiency Directive to include a new energy efficiency target of a 30\% reduction in energy by 2030. Individual national energy efficiency targets and action plans have been set from European Union (EU) countries to achieve the EU's 2020 target.

The recently revised (December 2018) Energy Performance of Buildings Directive (EPBD) is the main legislative instrument developed to realize the savings potential in the buildings sector targeting the long term decarbonization of the EU buildings stock (EC 2010). Given that the buildings account for almost $40 \%$ of the EU energy consumption, the importance of the implementation of EBBD is vital for achieving EU energy savings and carbon emission targets as well as to contribute to the Kyoto protocol targets. The Concerted Action EPBD is the board established by the European Commission in order to capitalize on, and foster, the directive's implementation in the $28 \mathrm{Mem}$ ber States (EC 2020). Early efforts concentrated on Energy Performance Certificates (EPCs) - who could use them, their form and content, and keeping track of them even after implementation. Later, however, issues gradually emerged - how good and reliable were they? Could they be used for informed decisions related to investment? Was there to be any quality control and enforcement by authorities, or was this just another piece of paper that someone needed to obtain and include in a purely administrative check, if any? These still partially open questions are creating room for improvements. According to Dovjak and Kukec, 2019 (Dovjak \& Kukec 2019), the consumption of heating oil between new and old building varies substantially with new buildings considered more effective (3-5 l/ $\mathrm{m}^{2} /$ year) compared to older buildings (25-60 l/ $\mathrm{m}^{2} /$ year). Currently, about $35 \%$ of Europe's buildings are more than 50 years old. Improving the energy efficiency of the existing building stock will significantly reduce energy consumption and $\mathrm{CO}_{2}$ emissions (EC 2020b).

The scope of this study is to present a comprehensive overview of the existing funding schemes in the EU for the energy upgrade of buildings. Following the introductory part, the study presents some crucial aspects of the European energy policy in the field, presenting some major supporting instruments. An analysis of the funding schemes in three different levels, according to the scale of investment, is presented in the third section of the study. Particularly the study analyses funding schemes for small scale projects (crowdfunding), mid-scale projects (Public-private partnership - PPP), and large-scale projects funded by European Investment Bank (EIB) and other funding institutions. The main findings of the study are presented in the conclusions section. 
Under the existing EPBD, the following measures must be applied:

- Buildings offered for rental or sale should enclose Energy Performance Certificates (EPCs);

- EU member states must establish inspection schemes of heating and air conditioning systems or measures with equivalent effect;

- all the newly constructed buildings should be nearly zero-energy by 31 st December 2020 (after 31 December 2018 for new public buildings occupied and owned by public authorities);

EU member states must establish national minimum energy performance requirements for new buildings, for the major renovation of buildings, and the replacement or retrofitting of building elements; and

EU member states should prepare national financial measures for improving the energy efficiency of the building sector.

The EU has released different support schemes and financial programs for the successful implementation of energy efficiency projects (Pyrgou et, al. 2016, Kylili \& Fokaides 2015, Fokaides \& Kylili 2014). Even though the EU has increased the public finance dedicated to energy efficiency, public funds alone are not sufficient for a clean energy transition. InFor this transition to happen, there is a need to trigger private energy efficiency investments. In this perspective, in 2018, the EC has released the Smart Finance for Smart Buildings (SFSB) initiative under 'Clean Energy for All Europeans' Communication as an effort to mobilize private financing on renewables sources and energy efficiency in buildings. The SFSB initiative aims to reinforced longer-term investments on energy projects in the building sector by allocating $€ 18$ billion between 2014 and 2020 . The current investment status lacks motivation from the investors resulting in low energy renovation rates ( 1\% /year) (EC 2019), while financial institutions arrange loans based on credits and property values discouraging the vulnerable consumers from investing in energy efficiency measures. To change these practices, SFSB target in three main goals:

To trigger private investments in energy efficiency through the intelligent use of EU grants as a guarantee. As part of the SFSB initiative, the Commission in conjunction with EIB, developed the "Guarantee facility" model under which the financial institutions can benefit from partial coverage of financial losses (70\%) when they deal with the uncertainty of innovative energy projects. This flexible model allows the development of innovative financing programs for the energy renovation of buildings by commercial banks or other intermediaries.

Help investors and financial institutions to assess the risks associated with energy investments as well as the obtained benefits by providing the De-risking Energy Efficiency Platform (DEEP 2020). The platform is an open-source database that contains data on energy efficiency projects, including monitoring, benchmarking and risk assessments. The users can use the platform to gain insights on energy investments risks based on real data, benchmark their projects compared to others as well as contribute for database enrichment

Offer technical and financial support to private and public building owners to implement investments in ambitious energy projects by setting up Project Development Assistance (PDA) facilities such as ELENA and PDA H2020. ELENA is managed by the EIB and provides financial support to large-scale energy-related projects above €30 million. The PDA H2020 supports the development of small and medium-scale energy projects of at least $€ 7.5$ million.

The latest development concerning funding schemes developed by the EU for its member states concerns the Innovation Fund (EC 2020c) (see Fig. 1). This initiative constitutes a financial support program that origins out of the EU emission trading scheme (ETS). The rationale behind this project is that part of the revenues, which results from carbon trading in the EU, will be invested in innovative projects related to the decarbonisation of the EU economy. The processor of the Innovation Fund is the NER300, which allowed the investment of over 2 billion EUR in the EU from 
Fig. 1

The Innovation Fund (2020-2030) of the European Union for investments for the decarbonization of the European Market

Funding Schemes for the Energy Upgrade of Buildings in Europe

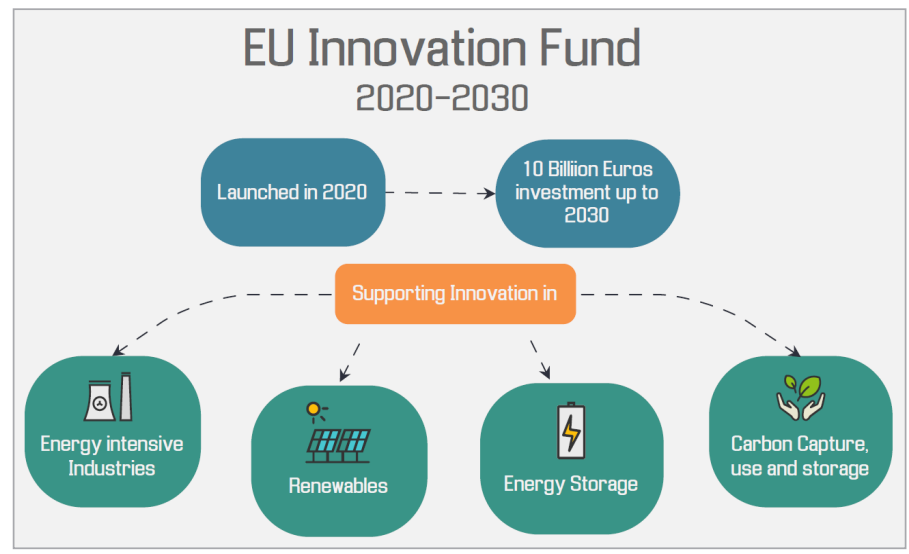

2012 to 2019. The new funding scheme is 5 times larger compared to its predecessor, and its scope is much wider, emphasizing the field of energy storage, as well as on energy intensive industries. The Commission also established the "EU Building Stock Observatory" which is used to track and publish energy performance related indicators of buildings across Europe (EC 2020d).

In this section, an overview of the main funding schemes in Europe for different scale projects is presented. Particularly funding schemes for small-scale projects initiated by the private sector (Crowdfunding), medium scale projects in which the private and public sector collaborate (PPP) and large-scale project funded by the public sector are presented. The analysed schemes, as well as their relation with the private and the public sector, are depicted in Fig. 2. The rationale of the study is that funding is classified in three levels of investment:

- Bottom layer investments are represented by a crowdfunding methodology for project of small entity (of max interventions of $€ 100,000$ ).

Second layer investments are proposed for medium size projects (up to €2 M) using public - private partnership (PPP) solution while for large scale projects,

- Top investments layer concerns funding opportunities at the European level (eg EIB)

\section{Crowdfunding}

Crowdfunding is considered to be an alternative practice of raising finance through standardized online processes. The crowdfunding has grown exponentially since 2012 to have considerable advantages compared to traditional financial instruments (Candelise, 2015). Traditionally, financing a project will require a large investments from a few individuals who will invest a large amount of money. Crowdfunding adopts a different mechanism that engages a large number of possible funders who are willing to invest in the implementation of a project or idea through the internet. The users have the option to choose among different investment options, therefore, covering different financial status. The online process of collecting the finances increases the speed of transac-

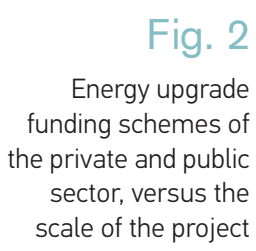

tion processing and the rate of raising funds. This has led to the discussion of whether such an alternative finance tool could be used in energy efficiency investments towards cleaner energy systems. Beyond an alternative method for raising funds, crowdfunding allows communities and citizens to become shareholders and share investments on ener- 
gy projects (CF4EE 2020). These approaches unlock new business models and can change the role of passive consumers to producers allowing citizens and individuals to become shareholders and benefit from the return on the investment. A presentation of crowdfunding's rationale is depicted in Fig. 3 .

Currently, the existing crowdfunding platforms for environmental campaigns mostly dominated by renewable energy projects. The most famous among the renewables are the photovoltaic and wind projects followed to a lesser extent by biomass and hydropower. Nonetheless, the degree of which this alternative financing method could be exploited still

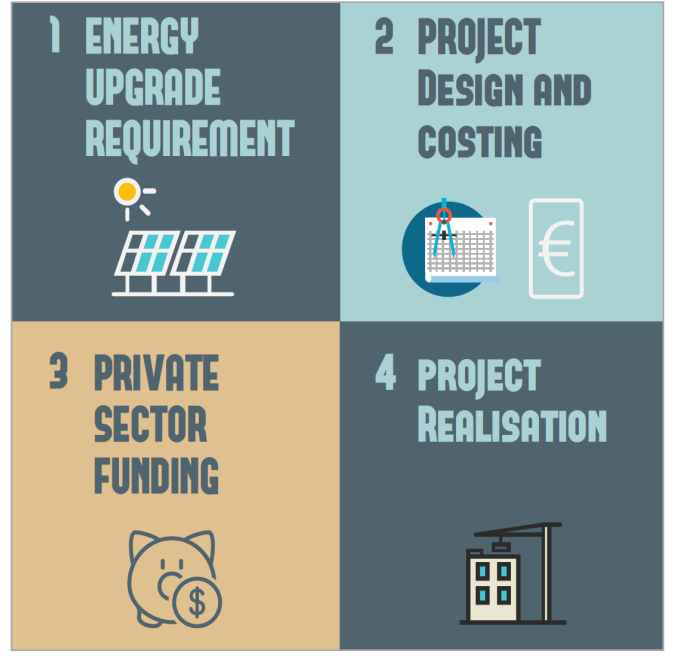
remains far from its full potential, especially for energy efficiency projects. As analysed and found out by other EU-funded projects such as Citizenergy and CrowdFundRes, there are significant barriers preventing individuals from understanding and investing through alternative financing mechanisms. Local Authorities can play a significant role in bridging public and alternative financial tools, given that the combination of such an investment will be a far more efficient technic of financing energy projects. This combination will enable ambitious energy projects to be implemented using citizen's collaboration while accelerating the implementation of EU's energy targets.

\section{Public-private partnerships (PPPs)}

Public-private partnerships (PPPs) is the collaboration of public and private sector for the purpose to implement public projects to use the resources and expertise of the private sector. PPPs allow large-scale government projects to be implemented in cases where the public sector is facing capital intensive projects, or more efficient services are required. The collaboration with the private sector can bring new solutions and finance, while the risks and responsibilities are being shared. This collaboration enables governments to focus on policy, planning, and regulation and the public sector to benefit from receiving the operating profits once the project is complete (Savas $\&$ Savas, 2000). Fig. 4 represents the main stages of PPP projects.

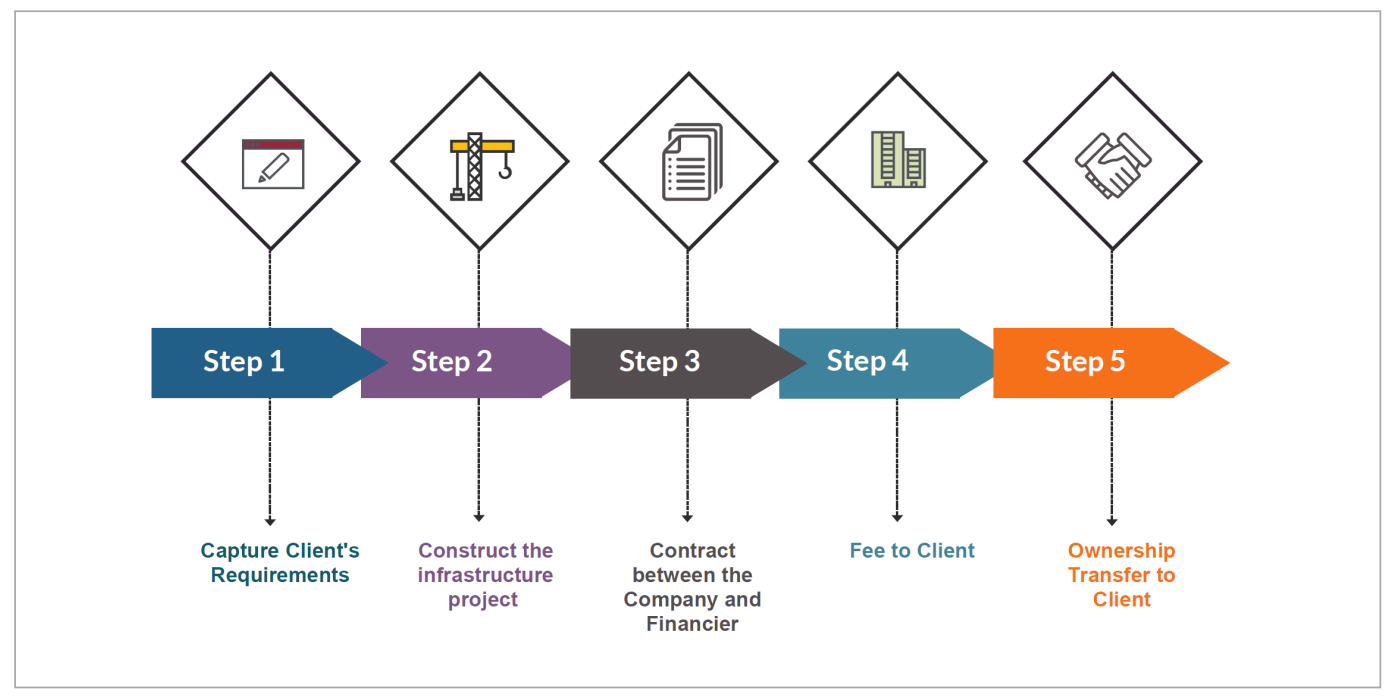

\section{Fig. 3}

The major steps of crowdfunding of projects for energy upgrade of buildings
Fig. 4

The major steps of private-public-partnership for medium-scale projects related to energy upgrade of buildings 
In the Energy sector, the main Public-Private agreements concern clean technology and energy efficiency and energy and power. In the first sector, renewable energies, power purchase agreements (PPAs) and carbon capture and storage are included, whereas, in the latter, PPAs, including transmission, distribution, and fuel supply are found. According to the "Review of the European PPP Market in 2018" published by the European Investment Bank, the value of PPP investments in EU market in 2018 was EUR 14.6 billion, of which seven projects were implemented in the environment and energy sector for a total value of EUR 2 billion (EIB 2020). While the number of PPPs in the energy sector that reached financial close has been relatively low in the last couple of years, their potential and impact are undoubtedly high. Moreover, the participation of Energy service companies (ESCOs) in PPP projects can be of high added value for PPP studies due to their focussed know-how, a high degree of specialisation and innovativeness. Such examples of successful projects are the Berlin Energy Saving Partnerships and Hungary "Szemünk Fenye Program". The first refers to the successful retrofit for public buildings initiated in Berlin in cooperation with Berlin Energy Agency (BEA). Based on Energy Performance Contracting (EPC) mechanisms and joint collaboration with ESCOs, a 26\% energy efficiency improvement was achieved over 1,400 successfully renovated buildings. Similarly, the "Szemünk Fenye Program" upgraded the indoor-lighting and heat supply in municipal and educational institutions in Hungary, based on multiyear service contracts ('Szemünk Fenye Program 2020). The best value-for-money ESCO provider was selected by the Ministry of Education, based on specific criteria such as pricing, experience, terms of the financial package, etc. Similar successful projects such as 'Energy Efficiency and Renewable Sources Fund' (EERSF) are also documented in Bulgaria.

\section{EU Public Funds for Energy Efficiency}

The ambitious targets set by the EU concerning the energy efficiency under the objectives of the 2020 and 2030 energy packages, aroused the need to increase the number of measures towards the clean energy transition. In this perspective, the number of public funds needed for the period 2021-2030 to reach the EU's energy and climate objectives for 2030 will be $€ 177$ billion per year (EC 2015). Currently, there are more than $60 \mathrm{EU}$ funds available (Euro funding database) concerning the Energy Sector, in which the most well-known are the European Energy Efficiency Fund (EEEF), the European Regional Development Fund (ERDF), the Joint European Support for Sustainable Investment in City Areas (JESSICA) and the European Local Energy Assistance (ELENA).

The European Energy Efficiency Fund (EEEF) (EC 2020e) is an initiative between the European Commission, the European Investment Bank (EIB), the Cassa Depositi e Prestiti (CDP), and Deutsche Bank. EEEF aims to support the EU target towards clean energy transition by providing financing to public projects related to energy saving and efficiency, renewable energy, and clean urban transport projects. Beneficiaries of the Fund could also be private entities in collaboration with public authorities

- The European Regional Development Fund (ERDF) (EC 2020f) is a financial instrument under the EU cohesion policy planning to deploy $€ 20$ billion from 2014-2020. This funding instrument aims to reduce regional disparities among different EU regions and to reinforce economic growth, sustainable development, and job creation. The Joint European Support for Sustainable Investment in City Areas (JESSICA) (EC 2020g) is an initiative by the European Commission in collaboration with the European Investment Bank (EIB) and the Council of Europe Development Bank (CEB) to support sustainable urban development. JESSICA supports investments financially on sustainable urban-renewal projects within the European Union with the option of using some of the EU Structural Funds. 
The European Local Energy Assistance (ELENA) (EIB 2020b) is a joint initiative by the EIB and the European Commission for technical and economic assistance on projects related to energy efficiency, renewable energy, and urban transport programs. ELENA supports projects above $€ 30$ million and covers up to $90 \%$ of technical assistance/project development costs. As of May 2019, 56 projects are ongoing under the ELENA fund, of which 1 in Lithuania, 1 in Greece, 3 in Germany, 4 in Germany, and 4 in Poland.

The EC is supporting several projects in the context of development and roll-out of innovative energy efficiency financing services. Among them, the following had the highest impact on the development of the financing schemes for energy projects support in the EU:

1. CITYnvest - Increasing the capacity in cities for innovative financing of energy efficiency (CITYnvest 2015-2018). This project strives to introduce innovative financing models in three pilot regions and to conduct a broad capacity-building program in 10 countries, related to specific financial instruments/business models.

2. CitizEE - Citizen Financing for energy efficiency (CitizEE 2019-2022). This project strives to support European public authorities to increase energy efficiency in the building sector by attracting private investments through crowdfunding and cooperative financing schemes.

3. EnPC-INTRANS - Capacity-building in energy performance contracting in European markets in transition (EnPC-INTRANS 2015-2017). This project aspired to increase the use of technologies used to support energy efficiency in public buildings. This goal was achieved by the joint collaboration of public Authorities and SMEs in setting-up and use adapted EnPC models for EE services.

4. EESI 2020 - the European Energy Service Initiative towards the EU 2020 energy-saving targets (EESI 2020), which aimed at fostering the use of Energy Performance Contracting in major cities and metropolitan regions across Europe.

5. ENERFUND - An ENErgy Retrofit FUNDing rating tool (ENERFUND 2016-2019). This project has developed a tool for identifying in-depth renovation opportunities based on different parameters such as EPC data, the number of certified installers, governmental schemes are running, etc. The aim was to enable building owners to make smart energy renovation decisions.

6. CrowdFundRES - Unleashing the potential of Crowdfunding for Financing Renewable Energy Projects (CrowdFundRES 2015-2018). Provides different layers of promotion (i.e., definition of toolkits/guidelines/recommendations for a wide range of stakeholders such as project's promoters/holders, project's backers/investors, definition of case studies, organisation and delivery of engagement events for selected stakeholders and general public) of crowdfunding as a financing tool for energy efficiency projects

7. Citizenergy - The european platform for CITIZEN investment in renewable ENERGY (Citizenergy 2014-2017). This project allows European citizens to participate in the EU's energy mix by giving them a chance invest in Renewable energy projects of their own decision. Under this EU funded project, an EU RES platform has been developed in which the European citizens can financially contribute and connect with each other

8. EnerSHIFT - Social Housing Innovative financing tender for energy (EnerSHIFT 2016-2020). This project aimed at energy renovation public housing in Liguria through innovative financing mechanisms by launching tenders for ESCO's Energy performance contracting (EPC) and low public fund

An overview of the EU funded research projects implemented from 2015 onwards for the upgrade of the energy performance of buildings is provided in Table 1.

\section{Research Projects for Financial Schemes for the Energy Upgrade of Buildings}




\section{Table \\ Overview of \\ EU funded \\ research projects implemented from \\ 2015 onwards for the upgrade of the energy performance of buildings}

\begin{tabular}{|c|c|c|c|}
\hline Project & Brief Description & $\begin{array}{l}\text { Implementation } \\
\text { Period }\end{array}$ & Coordinator \\
\hline $\begin{array}{l}\text { CITYnvest } \\
(2015-2018)\end{array}$ & $\begin{array}{l}\text { Supports the energy renovation of public buildings } \\
\text { and introduction of innovative financing models in } \\
\text { three regions: Belgium, Bulgaria and Spain. The } \\
\text { CITYnvest project document the successful financ- } \\
\text { ing models applied in the Euroepan Union and cre- } \\
\text { ate new models based on Energy Performance Con- } \\
\text { tracting (EPC), Third Party Financing (TPF), revolving } \\
\text { funds, cooperatives and others }\end{array}$ & $2015-2018$ & $\begin{array}{c}\text { Climate Alliance } \\
\text { - klima-buendnis } \\
\text { - alianza del clima } \\
\text { e.v. }\end{array}$ \\
\hline $\begin{array}{l}\text { CitizEE } \\
(2019-2022)\end{array}$ & $\begin{array}{l}\text { CitizEE is a European funded project in the context } \\
\text { of } \mathrm{H} 2020 \text { aimed to increase the energy efficiency } \\
\text { investments in the building sector. The project sup- } \\
\text { ports public Authorities to develop attractive finan- } \\
\text { cial models to trigger private investments }\end{array}$ & 2019-2022 & $\begin{array}{l}\text { Wirtschaft und } \\
\text { Infrastruktur } \\
\text { GMBH \& co } \\
\text { planungs kg }\end{array}$ \\
\hline $\begin{array}{l}\text { EnPC-INTRANS } \\
(2015-2017)\end{array}$ & $\begin{array}{l}\text { This H2O20 European funded project aspired to in- } \\
\text { crease the use of technologies used to support } \\
\text { energy efficiency in public buildings. This goal was } \\
\text { achieved by the joint collaboration of public Author- } \\
\text { ities and SMEs in setting-up and use adapted EnPC } \\
\text { models for EE services }\end{array}$ & $2015-2017$ & $\begin{array}{l}\text { Deutsche } \\
\text { Gesellschaft fur } \\
\text { Internationale } \\
\text { zusammenarbeit } \\
\text { (GIZ) GMBH }\end{array}$ \\
\hline EESI 2020 & $\begin{array}{l}\text { This European funded project supports the energy } \\
\text { plans of nine major cities and metropolitan regions } \\
\text { in Europe by enabling the long term implementation } \\
\text { of Energy performance contracting (EPC) }\end{array}$ & 2013-2016 & $\begin{array}{c}\text { Berliner } \\
\text { Energieagentur } \\
\text { GmbH }\end{array}$ \\
\hline $\begin{array}{l}\text { ENERFUND } \\
(2016-2019)\end{array}$ & $\begin{array}{l}\text { ENERFUND is a European funded project which as- } \\
\text { sesses deep renovation opportunities in buildings by } \\
\text { developing a rating tool based on a set of parame- } \\
\text { ters such as: EPC data, number of certified installers, } \\
\text { governmental schemes running, etc }\end{array}$ & 2016-2019 & $\begin{array}{l}\text { Technologiko } \\
\text { Panepistimio } \\
\text { Kyprou }\end{array}$ \\
\hline $\begin{array}{l}\text { CrowdFundRES } \\
(2015-2018)\end{array}$ & $\begin{array}{l}\text { CrowdFundRES supports the development of Re- } \\
\text { newable energy investments in European Union by } \\
\text { enabling the use of Crowdfunding. This European } \\
\text { funded project brings together three target groups: } \\
\text { Renewable energy project developers, Crowdfund- } \\
\text { ing platforms and Public. }\end{array}$ & $2015-2018$ & $\begin{array}{l}\text { Wirtschaft und } \\
\text { Infrastruktur } \\
\text { GMBH \& CO } \\
\text { planungs kg }\end{array}$ \\
\hline $\begin{array}{l}\text { Citizenergy } \\
(2014-2017)\end{array}$ & $\begin{array}{l}\text { This project allows European citizens to participate in } \\
\text { EU's energy mix by give them the chance invest in Re- } \\
\text { newable energy projects of their own decision. Under } \\
\text { this EU funded project, an EU RES platform has been } \\
\text { developed in which the European citizens can finan- } \\
\text { cially contribute and connect with each other }\end{array}$ & 2014-2017 & $\begin{array}{c}\text { Ateknea Solutions } \\
\text { Catalonia }\end{array}$ \\
\hline $\begin{array}{l}\text { EnerSHIFT } \\
(2016-2020)\end{array}$ & $\begin{array}{l}\text { This EU funded project aims to trigger energy retro- } \\
\text { fitting of social housing in Liguria Region by launch- } \\
\text { ing tenders for ESCO's Energy performance con- } \\
\text { tracting (EPC) and low public fund. }\end{array}$ & $2016-2020$ & Regione Liguria \\
\hline
\end{tabular}


The purpose of this study was to present the main financing tools for the energy upgrading of buildings in Europe. Particular emphasis was placed both on the presentation of European policy and the analysis of Crowdfunding, PPP, and public financing instruments. This work may form the basis for further research activities in the field of energy upgrades of buildings in Europe. Some of the significant findings of this study revealed that the energy-related funding schemes penetration defers in European member states in terms of advancement and implementation status.

Taking, for example, the 56 projects which are currently implemented in terms of the ELENA funding scheme, only 2 are realized in the three Baltic EU member states, and just one in the post-2008 EU member states (Bulgaria, Romania, Croatia). The situation is similar for southern EU member states, with just 1 project being implemented in Greece, Cyprus, Malta, and Portugal. On the other hand, countries like Denmark, Germany or The Netherlands present high numbers in ELENA projects (8, 4 and 4 respectively). The numbers are similar for other funding schemes related to buildings energy efficiency. It goes without saying that if no concrete actions are taken in this field, the gap between south-eastern Europe on the one hand and central-north Europe on the other will be increasing. As an important parameter that must be stated in the stage is the National energy efficiency financial mechanisms of EU MS. No country can ignore the development, social and economic opportunities that are being unleashed by relevant energy efficiency policies and measures around the world. Therefore EU member states must be give primary consideration in national energy policies and energy efficiency financial schemes that should be integrated into mainstream economic planning of local government and business development processes in general. The imperative norm that any project idea to be implemented in this field should consider this chasm and take the appropriate actions to boost the economic activities for smart tools and practices targeted to buildings energy upgrades.

Szemünk Fenye Program (2020). Available at: http:// www.nefmi.gov.hu/szemunkfenye, Last accessed 09.03.2020

Candelise, C. (2015). Crowdfunding and the Energy Sector. Exchange.

CF4EE - Crowdfunding for Energy Efficiency (2020). Available at: www.ieadsm.org, Last accessed 09.03.2020

Citizenergy (2014-2017) - The european platform for Citizen investment in renewable Energy. Available at: https://citizenergy.eu/, Last accessed 09.03.2020

De-Risking energy efficiency platform (DEEP) (2020). Available at: https://deep.eefig.eu/, last access 02.03.2020

Dovjak, M., \& Kukec, A. (2019). Creating Healthy and Sustainable Buildings. Springer Open: Cham, Switzerlandhttps://doi.org/10.1007/978-3-030-19412-3

EESI 2020 - the European Energy Service Initiative towards the EU 2020 energy-saving targets. Available at: http://eesi2020.eu/about-eesi-2020/, Last accessed 09.03.2020

European Commission (2010). Energy Performance of Buildings Directive 2010/31/EU (EPBD) available at: https://eur-lex.europa.eu/eli/dir/2010/31/oj, last access 02.03.2020
European Commission (2012). The Energy Efficiency Directive (2012/27/EU) available at: https://eurlex.europa.eu/legal-content/EN/TXT/?uri=celex\%3A32012L0027: last access 02.03.2020

European Commission (2015). Financing Energy Efficiency (2015) available at: https://ec.europa.eu/energy/topics/energy-efficiency/financing-energy-efficiency_en, Last accessed 09.03.2020

European Commission (2019). Comprehensive study of building energy renovation activities and the uptake of nearly zero-energy buildings in the EU available at: https://ec.europa.eu/energy/sites/ener/files/documents/1.final_report.pdf: last access 02.03.2020

European Commission (2020). Concerted Action EPBD available at: https://epbd-ca.eu/, last access 02.03.2020 European Commission (2020b). New rules for greener and smarter buildings will increase quality of life for all Europeans available at: https://ec.europa.eu/ info/news/new-rules-greener-and-smarter-buildings-will-increase-quality-life-all-europeans-2019apr-15_en, last access 02.03.2020

European Commission (2020c). Innovation Fund. Available at: https://ec.europa.eu/clima/policies/ innovation-fund_en, Last accessed 07.03.2020

European Commission (2020d). Building Stock Ob-

\section{References}


servatory available at: https://ec.europa.eu/energy/ topics/energy-efficiency/energy-efficient-buildings/ eu-bso_en, Last accessed 09.03.2020

European Commission (2020e). European Energy Efficiency Fund EEEF available at: www.eeef.eu, Last accessed 09.03.2020

European Commission (2020f). European Regional Development Fund available at: https://ec.europa. eu/regional_policy/en/funding/erdf/, Last accessed 09.03.2020

European Commission (2020g). JESSICA: Joint European Support for Sustainable Investment in City Areas available at: https://ec.europa.eu/regional_policy/archive/thefunds/instruments/jessica_en.cfm, Last accessed 09.03.2020

European Investment Bank (EIB) (2020). Market Update - Review of the European PPP Market in 2018 available at: www.eib.org, Last accessed 09.03.2020 European Investment Bank (EIB) (2020b). ELENA - European Investment Bank available at: https:// www.eib.org/en/products/advising/elena/index. htm, Last accessed 09.03.2020

Fokaides, P. A., \& Kylili, A. (2014). Towards grid parity in insular energy systems: The case of photovoltaics (PV) in Cyprus. Energy Policy, 65, 223-228.https:// doi.org/10.1016/j.enpol.2013.10.045

H2020 CitizEE (2019-2022) - Citizen Financing for energy efficiency. Available at: https://www.citizee.eu/, Last accessed 09.03.2020
H2020 CITYnvest (2015-2018) - Increasing the capacity in cities for innovative financing of energy efficiency available at: http://citynvest.eu/, Last accessed 09.03.2020

H2020 CrowdFundRES (2015-2018) - Unleashing the potential of Crowdfunding for Financing Renewable Energy Projects. Available at: http://www. crowdfundres.eu/, Last accessed 09.03.2020

H2020 ENERFUND (2016-2019) - An ENErgy Retrofit FUNDing rating tool. Available at: http://enerfund.eu/, Last accessed 09.03.2020

H2020 EnerSHIFT (2016-2020) - Social Housing Innovative financing tender for energy. Available at: https://enershift.eu/, Last accessed 09.03.2020

H2020 EnPC-INTRANS (2015-2017) - Capacity-building in energy performance contracting in European markets in transition. Available at: https://www.enpc-intrans.eu, Last accessed 09.03.2020

Kylili, A., \& Fokaides, P. A. (2015). Competitive auction mechanisms for the promotion renewable energy technologies: The case of the $50 \mathrm{MW}$ photovoltaics projects in Cyprus. Renewable and Sustainable Energy Reviews, 42, 226-233.https://doi.org/10.1016/j.rser.2014.10.022

Pyrgou, A., Kylili, A., \& Fokaides, P. A. (2016). The future of the Feed-in Tariff (FiT) scheme in Europe: The case of photovoltaics. Energy Policy, 95, 94-102https://doi.org/10.1016/j.enpol.2016.04.048

Savas, E. S., \& Savas, E. S. (2000). Privatization and public-private partnerships.

\section{About the Authors}

\section{CHRISTIANA PANTELI \\ Research associate \\ in Cleopa $\mathrm{GmbH}$ and a \\ PhD Student \\ Frederick University, \\ Cyprus, School of \\ Engineering}

Main research area

Energy and Buildings,

Digital Construction

Design Tools

Address
Neuendorfstr. 18b
LT-16761 Hennigsdorf,
Germany
Tel.: +49 3302 / 2069295
E-mail:
cpanteli@cleopa.de

\section{EGLE் KLUMBYTÉ}

Lecturer

Kaunas University of Technology, Faculty of Civil Engineering and Architecture

Main research area
Construction
Management,
Building Sustainability

Address

48, Studentu Str., 51367 , Kaunas, Lithuania Tel.: +370 (37) 300000 E-mail: egle.klumbyte@ktu.lt
RASA APANAVIČIENĖ

Associate Professor

Kaunas University of Technology, Faculty of Civil Engineering and Architecture

\section{Main research area}

Construction Management, Building Sustainability

\section{Address}

48, Studentu Str., 51367 ,

Kaunas, Lithuania

Tel.: +370 (37) 300000

E-mail:

rasa.apanaviciene@ktu.lt
PARIS FOKAIDES

Assistant Professor

Frederick University, Cyprus, School of Engineering, and a Chief Researcher at Kaunas University of Technology, Faculty of Civil Engineering and Architecture

Main research area

Sustainable Energy Systems, Energy and Buildings

\section{Address}

7, Frederickou Str., 1036, Nicosia, Cyprus

Tel.: +35722 394394

E-mail: eng.fp@frederick.ac.cy 